\title{
PENGARUH FITUR KARAKTER TERHADAP SIKAP KONSUMEN ATAS MEREK MELALUI KEPERCAYAAN KARAKTER PADA PRODUK ES KRIM PADDLEPOP
}

\author{
Bambang Setyadarma \\ Fakultas Ekonomi Universitas Wijaya Kusuma Surabaya \\ e-mail: bsbambang1@gmail.com
}

\begin{abstract}
This research goal is to measure the influence of Character feature for Customer Atitude on the Brand through the Trust of Character for Paddlepop Ice Cream Product. Samples of this research used 115 respondents. The Sampling technique use non probability sampling (direct of sampling method). Finaly, these research implication try to explain that the Character Feature at the variances: Expertise on Trust of Customer, Relevance for Trust of Customer, and Nostalgy for Trust of Customer have a significant influences to consumer attitude which hypothesis test under level of tolerance about 5\%. This research also find that Trust of Customer has an influent to The Customer Atitude. Critical Path Coefficient Analysis of Expertise to The Trust of Customer about 26,5\%, Relevancy on The Trust of Customer about 63,8\%, Nostalgy on The Trust of Customer about 55,5\% and Trust of Customer to The Customer Atitude for Brand about 3,4\%. So this research accepted Hypotesis of 1, Hypotesis of 2, Hypotesis of 3, Hypotesis of .
\end{abstract}

Keywords: character of feature, trust of customer, customer atitude to the brand

\section{PENDAHULUAN}

Salah satu cara perusahaan untuk menawarkan produk maupun jasanya kepada konsumen adalah promosi. Suatu rangkaian promosi yang efektif dan efisien dapat menarik perhatian konsumen di dalam suatu aktivitas persaingan antar entitas bisnis. Spokes Character merupakan salah satu alat komunikasi yang penting (Philip dan Gyoerick, 1999). Sejak lama Spokes Character digunakan dalam promosi. Para ahli juga merekomendasikan Spokes Character sebagai salah satu bentuk periklanan yang paling efektif. Spokes Character menurut Garretson dan Niedrich (2004) merupakan suatu animasi atau objek yang digunakan untuk mempromosikan produk, layanan, merek, atau ide yang memiliki kepribadian yang unik dan karakteristik tersendiri guna menarik perhatian dari konsumen. Spokes Character tidak harus merupakan suatu merek dagang yang bersifat legal tetapi harus secara konsisten digunakan dalam menghubungkan suatu produk sepanjang waktu (Philip dan Gyoerick, 1999).

Tipe Spokes Character pada umumnya dapat dibedakan menjadi berikut: (1) Menurut deskripsi dari Spokes Character, diantaranya: animasi manusia yang dapat dibedakan menjadi dua yaitu riil dan fiksi, hewan yang berperilaku seperti manusia, dan produk yang berperilaku seperti manusia, (2) Menurut perilaku karakter, yaitu: apakah karakter berbicara mengenai produk atau menyediakan demonstrasi visual mengenai produk, (3) Menurut status selebriti, yaitu: selebriti (tidak berasal dari periklanan) dan non-selebriti (berasal dari periklanan), (4) Menurut gender karakter yaitu laki-laki, perempuan, laki-laki dan perempuan, atau tidak dapat dibedakan (Callcott dan Lee, 1994).

Berdasarkan hasil analisis wawancara mendalam Callcott dan Philip dalam Garretson dan Niedrich (2004) diketahui bahwa konsumen memperhatikan faktor-faktor dari karakter seperti nostalgia, relevansi terhadap produk, dan keahlian. Berdasarkan hasil riset Callcott dan Lee (1994) diketahui hasil content analysis iklan televisi dan iklan cetak menyatakan bahwa: (1) Spokes Character digunakan untuk mempromosikan beberapa tipe produk dan jasa, (2) Tipe Spokes Character yang bersifat spesifik seringkali menjadi ciri suatu produk, (3) Para praktisi muncul untuk mempertimbangkan kualitas nostalgia dan relevansi karakter terhadap produk yang diiklankan.

Menurut Garretson dan Niedrich (2004) diketahui bahwa karakter dapat menciptakan persepsi akan kepercayaan yang muncul untuk 
mempengaruhi sikap serta perilaku konsumen. Garretson dan Niedrich (2004) menyatakan bahwa konsumen menyukai dan seringkali mengekspresikan kepercayaan serta menerima terhadap Spokes Character. Konsumen cenderung menilai kualitas Spokes Character layaknya manusia. Seiring dengan berkembangnya seni serta teknologi animasi, persepsi bahwa Spokes Character seperti manusia dan memiliki jiwa tidaklah mengejutkan. Kepercayaan Konsumen atas Spokes Character dapat memberikan anggapan bahwa konsumen cenderung menyukai dan membeli produk dari karakter yang dipercaya (Garretson dan Niedrich, 2004). Dengan adanya Kepercayaan maka Sikap terhadap Merek diharapkan dapat bertambah baik.

Hubungan antara penggunaan Spokes Ccharacter dengan sikap terhadap merek cenderung bersifat positif dan beberapa studi sebelumnya telah mulai secara spesifik dan empiris mengidentifikasi tipe kualitas karakter yang bertanggung jawab atas hubungan tersebut. Salah satu penelitian yang mencoba meneliti adanya hubungan antara fitur Spokes Character (Relevansi, Keahlian, dan Nostalgia), Kepercayaan Konsumen atas Spokes Character, dan Sikap terhadap Merek adalah penelitian yang dilakukan oleh Garretson dan Niedrich (2004).

Dalam penelitian ini, tipe Spokes Character yang akan diteliti adalah Spokes Character yang tergolong non-selebriti. Jadi, karakter tersebut bukanlah karakter yang dibuat khusus untuk film, program kartun, atau komik dan kemudian dilisensi oleh suatu merk untuk muncul dalam promosinya, melainkan diciptakan hanya untuk tujuan mempromosikan suatu produk atau merek. Spokes Character yang akan dijadikan objek dalam penelitian ini adalah Lion. Lion merupakan Spokes Character dalam kegiatan promosi produk ice cream Paddlepop yang diproduksi oleh PT. Unilever Indonesia. Secara visual, figur Lion dikenal berupa karakter kartun singa yang menyerupai tingkah manusia yang dapat berjalan, melompat, berlari yang suka dengan petualangan dan berbaju ala china berwarna merah dan kuning. Karakter Lion selain tampil pada iklan televisi, juga tampil pada setiap kemasan Paddlepop sehingga karakter tersebut tampaknya sudah tidak asing lagi bagi konsumen.

Ice cream Paddlepop telah dipasarkan sejak tahun 1992. Target utama dari ice cream ini adalah anak-anak hingga remaja. Tetapi, meskipun ditujukan untuk konsumen anak-anak hingga remaja. Produk ini ternyata juga disukai konsumen dewasa. Karakter Lion yang selalu muncul pada setiap kemasan maupun iklan ice cream Paddlepop menjadikannya dekat di hati kebanyakan masyarakat Indonesia yang tumbuh dengannya. Hal ini yang membuat Karakter Lion menjadi obyek yang menarik untuk diteliti apakah memang keberadaan karakter tersebut dalam promosi benarbenar dapat menciptakan suatu kepercayaan konsumen.

\section{Spokes Character}

Menurut Philip dan Gyoerick (1999) Spokes Character adalah suatu animasi atau obyek yang dianimasikan yang digunakan untuk mempromosikan suatu produk, jasa atau ide. Spokes Character tidak harus merupakan suatu merek dagang yang bersifat legal atau muncul di kemasan tetapi harus secara konsisten digunakan dalam menghubungkan dengan suatu produk sepanjang waktu.

\section{Karakter Keahlian}

Ohanian (1990) menyatakan bahwa keahlian merupakan suatu persepsi bahwa sumber mampu untuk membuat pernyataan yang benar atau memiliki pengetahuan atas produk.

Beberapa studi menunjukkan bahwa penonton akan menerima pernyataan dari sumber yang dianggap lebih berpengetahuan dibanding dirinya sendiri pada persoalan tertentu. Penerimaan penonton akan meningkat seiring dengan keahlian sumber dan ketidakmampuan penonton untuk mengevaluasi produk (Tellis, 2004:181).

\section{Karakter Relevansi}

Garretson dan Niedrich (2004) melaporkan bahwa konsumen benar-benar mempertimbangkan pentingnya kecocokan antara karakter dan produk.

Menurut Garretson dan Niedrich (2004) bahwa Relevansi merupakan tingkatan dimana dua stimuli sesuai atau cocok bersama. Cocok dalam konteks Spokes Character merupakan tingkat dimana Spokes Character diharapkan dapat cocok atau serasi dengan produk yang dihubungkan dengannya dalam kampanye promosi.

\section{Karakter Nostalgia}

Organisasi menyadari kekuatan Nostalgia dan menguntungkan konsumen dan Pengaruh baiknya terhadap Merek (Garretson dan Niedrich, 2004). Pengertian Nostalgia sendiri merupakan ingatan dari seseorang atau peristiwa yang lalu.

Dalam penelitiannya, Garretson dan Niedrich (2004) berpendapat bahwa Spokes Character 
merupakan gambaran Nostalgia. Konsumen diekspos dengan karakter pada usia muda yaitu sejak beberapa karakter menjadi endorser produk anak-anak. Spokes Character tersebut bertahan dari generasi ke generasi dan dapat mempertahankan kehadirannya secara konstan dalam kehidupan konsumen dengan kemunculannya dalam iklan, kemasan produk, dan promosi penjualan. Selain itu, Spokes Character juga digunakan untuk mengingatkan kembali konsumen akan merek yang telah mereka gunakan dan percayai sejak kanak-kanak.

Beberapa perusahaan memperkenalkan kembali slogan serta karakter mereka dari masa lalu, sementara yang lain hanya mengingatkan kembali konsumen tentang merek yang pernah menjadi bagian hidup mereka selama beberapa tahun.

\section{Kepercayaan Konsumen atas Spokes Character}

Kepercayaan merupakan harapan atas integritas, ketulusan, dan kejujuran dari suatu obyek (Garretson dan Niedrich, 2004). Sedangkan Kotler dan Keller (2006:506) menyatakan bahwa Kepercayaan berhubungan dengan seberapa obyektif dan jujur suatu sumber.

Kepercayaan Konsumen atas Spokes Character sangat penting karena dapat memberikan anggapan bahwa konsumen cenderung untuk menyukai dan membeli produk dari karakter yang dipercaya (Garretson dan Niedrich, 2004). Berdasarkan hasil penelitian Luo, McGoldrick, Beatty, dan Keeling (1996) juga diketahui bahwa konsumen lebih cenderung mempercayai karakter kartun daripada karakter berupa manusia.

Kerangka konseptual penelitian menjelaskan bahwa dimensi Spoke Character yang terdiri dari Keahlian, Relevansi dan Nostalgia saling berinteraksi kausal melalui Kepercayaan Konsumen dan berkorelasi faktual terhadap Stimuli Sikap Konsumen atas Merek suatu Produk (Garretson dan Niedrich, 2004).

\section{Metode Rancangan Penelitian}

Berdasarkan latar belakang serta tujuan penelitian, hipotesis yang diajukan adalah:

$\mathrm{H}_{1}$ : Fitur Keahlian berpengaruh signifikan terhadap Kepercayaan Konsumen atas Spokes Character Lion Paddlepop Ice Cream.

$\mathrm{H}_{2}$ : Fitur Relevansi berpengaruh signifikan terhadap Kepercayaan Konsumen atas Spokes Character Lion Paddlepop Ice Cream.

$\mathrm{H}_{3}$ : Fitur Nostalgia berpengaruh signifikan terhadap Kepercayaan Konsumen atas Spokes Character Lion Paddlepop Ice Cream.

$\mathrm{H}_{4}$ : Kepercayaan Konsumen atas Spokes Character Lion berpengaruh signifikan terhadap Sikap Konsumen atas produk Lion Paddlepop Ice Cream.

\section{Definisi Operasional dan Pengukuran Variabel}

Fitur Keahlian $\left(\mathrm{X}_{1}\right)$, merupakan suatu persepsi yang mengukuhkan bahwa karakter Lion memiliki Keahlian dalam mempromosikan produk ice cream Paddlepop.

Fitur Relevansi $\left(\mathrm{X}_{2}\right)$, merupakan tingkat dimana karakter Lion diharapkan dapat cocok atau serasi dengan produk ice cream Paddlepop.

Fitur Nostalgia $\left(\mathrm{X}_{3}\right)$, merupakan kemampuan karakter Lion untuk dapat mengingatkan kembali kejadian atau ingatan masa lalu.

Kepercayaan Konsumen atas Spokes Character (Intervening), merupakan harapan konsumen bahwa karakter Lion dapat dipercaya dalam memberikan informasi atau mempromosikan produk ice cream Paddlepop.

Sikap terhadap Merek (Y), merupakan kecenderungan konsumen untuk mengevaluasi Lion dengan menunjukkan rasa suka maupun tidak suka dengan konsisten.

Teknik pengukuran variabel menggunakan Skala Likert 5 poin (sangat tidak setuju, tidak setuju, netral, setuju, sangat setuju), sebagaimana halnya penelitian sebelumnya yang telah dilakukan Garretson dan Niedrich (2004).

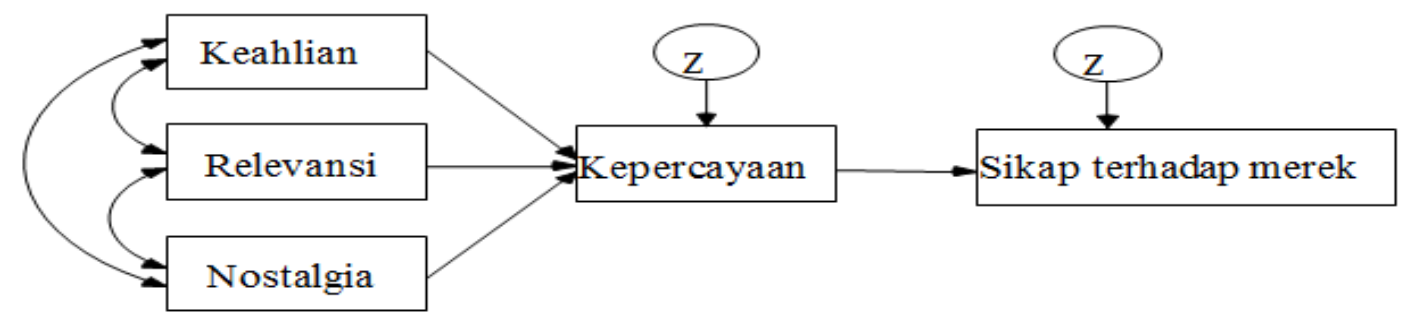

\section{Gambar 1 \\ Kerangka Konseptual}




\section{METODE PENELITIAN}

\section{Teknik Penentuan Sampel}

Sampel penelitian terdiri dari 115 partisipan pengunjung BG Junction Surabaya yang mengenal Karakter Lion sebagai Spokes Character produk ice cream Paddlepop melalui berbagai media promosi serta pernah mengkonsumsi produk tersebut. Pengambilan sampel dilakukan secara non probabilitas menggunakan metode judgement sampling, dimana peneliti memilih sampel berdasarkan penilaian terhadap aspek lokasi penelitian, proporsionalitas jumlah sampling penelitian, sejauhmana selera partisipan penelitian terhadap merek ice cream paddlepop, kejelasan arah serta manfaat produk ice cream paddlepop bagi partisipan penelitian khususnya (Kuncoro, 2003:119).

\section{Metode Analisis Data}

Analisis data penelitian ini, menggunakan pendekatan Structural Equation Modeling (SEM) guna mengukur relevansi covariance construct antar elemen-elemen indikator parameter penelitian disertai pengukuran konseptual hubungan serta pengaruh langsung maupun tidak langsung terhadap parameter endogenous maupun parameter intervening secara faktual beserta implikasinya (Agustinus, 2016).

\section{Tabel 1}

Uji Validitas

\begin{tabular}{cccc}
\hline $\begin{array}{c}\text { Butir } \\
\text { Pernyataan }\end{array}$ & r-hitung & r-tabel & Validitas \\
\hline Keahlian 1 & 0,336 & 0,119 & Valid \\
\hline Keahlian 2 & 0,288 & 0,119 & Valid \\
\hline Keahlian 3 & 0,398 & 0,119 & Valid \\
\hline Relevansi 1 & 0,346 & 0,119 & Valid \\
\hline Relevansi 2 & 0,326 & 0,119 & Valid \\
\hline Nostalgia 1 & 0,380 & 0,119 & Valid \\
\hline Nostalgia 2 & 0,332 & 0,119 & Valid \\
\hline
\end{tabular}

(Sumber: Data diolah)

\section{Hasil}

\section{Uji Validitas}

Uji validitas dilakukan terhadap masing-masing butir pernyataan variabel Keahlian, Relevansi dan Nostalgia. Untuk variabel Kepercayaan atas Spokes Character dan Sikap terhadap Merek tidak dapat diuji tingkat validitasnya karena hanya memiliki 1 butir pernyataan saja. Dijelaskan bahwa 9 butir pernyataan variabel keahlian, relevansi, nostalgia kesemuanya adalah valid. Dimana butir-butir pernyataan variabel penelitian tersebut memiliki nilai r-korelasi totalnya berada di atas standart nilai r-tabelnya. Sehingga dapat disimpulkan bahwa kesemua butir pernyataan variabel Keahlian, Relevansi maupun Nostalgia memiliki tingkat validitas yang cukup sahih (Santoso, 2004:19).

Tabel 2

Uji Reliabilitas

\begin{tabular}{cccc}
\hline Variabel & Koefisien & Alpha & Reliabilitas \\
\hline Keahlian & 0,784 & $>0,6$ & Reliabel \\
\hline Relevansi & 0,786 & $>0,6$ & Reliabel \\
\hline Nostalgia & 0,882 & $>0,6$ & Reliabel
\end{tabular}

(Sumber: Data diolah)

\section{Uji Reliabilitas}

Uji reliabilitas dilakukan terhadap parameter Spokes Character yang terdiri dari: Keahlian, Relevansi, maupun Nostalgia. Dapat disimpulkan bahwa ke 3 (tiga) parameter Spokes Character memiliki tingkat keandalan/reliabilitas yang cukup baik, atas konsistensi alat ukurnya dari waktu ke waktu. Dimana koefisien Cronbach Alphanya berada di atas Alpha Standart sebesar 0,6 (Santoso, 2004:20).

\section{Proporsionalitas Ukuran Sampel}

Ukuran sampel yang digunakan dalam penelitian ini sebanyak minimal 5 kali jumlah observasi untuk setiap indikator sesuai dengan yang diungkapkan oleh Hair, et al (1998:98). Penelitian ini memiliki 9 observasi dengan rincian: 3 observasi untuk variabel Karakter Keahlian, 2 observasi untuk variabel Karakter Relevansi, 2 observasi untuk variabel Karakter Nostalgia, 1 observasi untuk variabel Kepercayaan Konsumen atas Spokes Character, dan 1 observasi untuk variabel Sikap terhadap Merek. Sehingga jumlah sampel 115 responden dianggap telah memenuhi syarat tersebut. 


\section{Uji Normalitas Data}

Pengujian normalitas data dilakukan dengan menggunakan nilai critical ratio (CR) perhitungan skewness dan kurtosis. Asumsi terpenuhi jika nilai CR berada diantara $+2,58$ dan $-2,58$ dengan tingkat signifikansi $1 \%$. Apabila nilai CR berada di luar rentang nilai tersebut maka data tidak terdistribusi secara normal. Dijelaskan bahwa data telah terdistribusi secara normal dengan nilai $\mathrm{CR}$ skewness dan kurtosis antara $+2,58$ dan $-2,58$.

\section{Uji Outlier Data}

Deteksi terhadap adanya outlier dapat dilakukan dengan 2 cara yaitu melalui analisis univarite outlier dan multivariate outlier. Analisis univariate outlier melibatkan perkiraan terhadap $z$ score. Untuk sampel besar (diatas 80 data observasi), pedoman evaluasi adalah bahwa nilai ambang batas dari z-score itu berada pada rentang 3 sampai dengan 4. Oleh karena itu kasus-kasus atau observasi-observasi yang mempunyai z-score kurang dari sama dengan -3 atau lebih dari sama dengan 3 akan dikategorikan sebagai outliers (Hair dkk dalam Ferdinand, 2005:143). Adanya outlier secara univariat pada item Sikap terhadap Merek.

Sedangkan multivariate outlier dilakukan melalui pemeriksaan pada jarak mahalanobis yang dibandingkan dengan nilai chi-square. Pedoman evaluasi adalah nilai chi-square dengan derajat bebas minimal sebesar 3 pada tingkat signifikansi 0,001 yaitu 11,345. Apabila kasus atau observasi mempunyai nilai mahalanobis distance lebih besar dari 11,345 maka akan dikategorikan sebagai outliers. Pada tabel 5 indikasi observasi yang terkategorikan sebagai outliers. Meskipun terdapat adanya outliers, observasi tersebut tidak dapat dieleminasi. Menurut Ferdinand, (2005:153), apabila tidak terdapat alasan khusus untuk mengeluarkan kasus yang mengindikasikan adanya outliers, maka kasus itu harus tetap diikutsertakan dalam analisis selanjutnya.

Tabel 3

Normalitas Data

\begin{tabular}{lcccc}
\hline Parameter Penelitian & SKEWNESS & CR & KURTOSIS & CR \\
\hline Keahlian & $-1,191$ & $-1,216$ & 1,367 & 2,192 \\
\hline Relevansi & $-1,482$ & $-2,111$ & $-1,381$ & $-2,334$ \\
\hline Nostalgia & $-1,183$ & $-1,803$ & $-1,092$ & $-2,390$ \\
\hline Kepercayaan & $-1,116$ & $-1,508$ & $-1,627$ & $-1,373$ \\
\hline Sikap terhadap merek & $-1,977$ & $-1,653$ & 2,625 & 2,136 \\
\hline Multivariate & & & 4,197 & 2,470 \\
\hline
\end{tabular}

(Sumber: Data diolah)

\section{Uji Multikolinieritas}

Bertujuan untuk menguji apakah ditemukan adanya korelasi antar variabel bebas. Untuk mendeteksi ada atau tidaknya multikolinieritas di dalam suatu model dapat dilakukan dengan menganalisis matriks korelasi variabel independen. Jika antar variabel bebas terdapat korelasi yang cukup tinggi (umumnya di atas 0,9), maka hal ini mengindikasikan adanya multikolinieritas (Ghozali, 2005:91). Pada tabel 6 tidak ditemukan adanya indikasi terjadinya multikolinieritas karena tidak ada korelasi yang melebihi 0,90.
Tabel 4

Univariate Outliers

\begin{tabular}{ccc}
\hline Item & $\begin{array}{c}\text { z-score } \\
\text { min }\end{array}$ & $\begin{array}{c}\text { z-score } \\
\max \end{array}$ \\
\hline Keahlian 1 & $-2,06674$ & 1,35304 \\
\hline Keahlian 2 & $-1,54134$ & 1,80640 \\
\hline Keahlian 3 & $-2,28714$ & 1,58338 \\
\hline Relevansi 1 & $-1,63124$ & 1,60308 \\
\hline
\end{tabular}




\begin{tabular}{ccc}
\hline Relevansi 2 & $-2,63199$ & 1,65190 \\
\hline Nostalgia 1 & $-2,88427$ & 2,77409 \\
\hline Nostalgia 2 & $-2,21746$ & 1,09750 \\
\hline Kepercayaan & $-2,94026$ & 1,79217 \\
\hline $\begin{array}{c}\text { Sikap } \\
\text { terhadap }\end{array}$ & $-1,92535$ & 1,48196 \\
\hline (Sumber: Data diolah) &
\end{tabular}

Tabel 5

Multivariate Outlier

\begin{tabular}{ccl}
\hline $\begin{array}{c}\text { No. } \\
\text { Observasi }\end{array}$ & $\begin{array}{c}\text { Mahalanobis } \\
\text { d-squared }\end{array}$ & Keterangan \\
\hline 3 & 17,745 & Outlier \\
\hline 4 & 17,653 & Outlier \\
\hline 17 & 16,439 & Outlier \\
\hline 18 & 16,320 & Outlier \\
\hline 86 & 13,946 & Outlier \\
\hline 5 & 13,481 & Outlier \\
\hline 89 & 12,715 & Outlier \\
\hline 88 & 12,266 & Outlier \\
\hline 87 & 12,266 & Outlier \\
\hline 12,266 & Outlier \\
\hline
\end{tabular}

(Sumber: Data diolah)

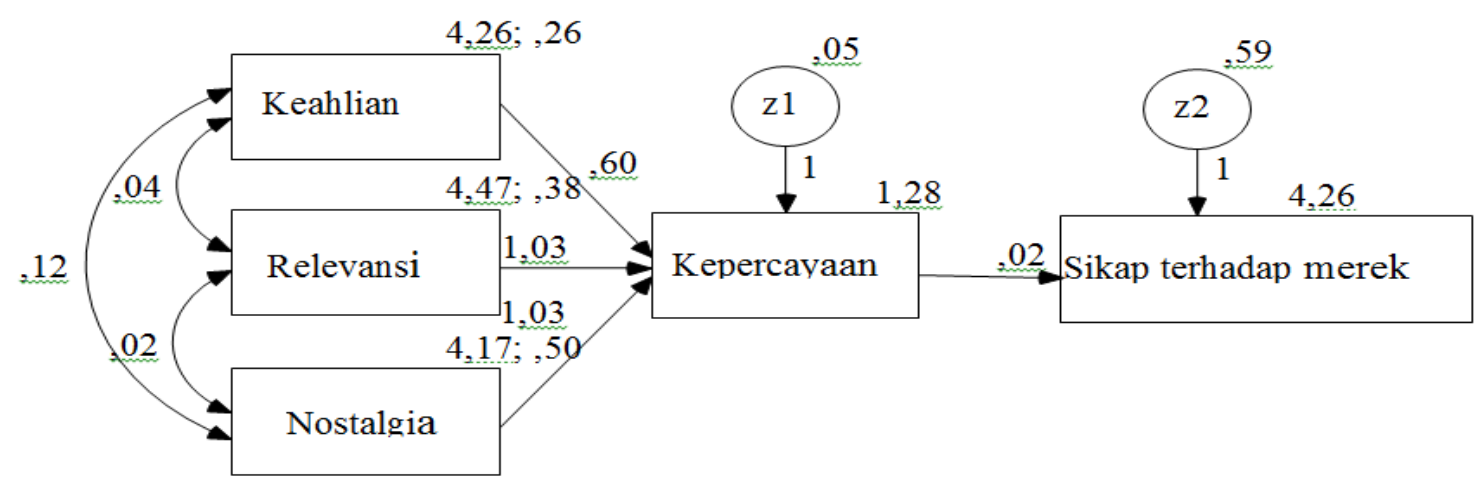

Gambar 2

Hasil Analisa 
Tabel 8

Hasil Pengujian Hipotesis

\begin{tabular}{clccc}
\hline Hipotesis & \multicolumn{1}{c}{ Pengaruh } & CR & P & Keterangan \\
\hline H1 & Keahlian $\rightarrow$ Kepercayaan & 13,602 &, 000 & Diterima \\
\hline H2 & Relevansi $\rightarrow$ Kepercayaan & 32,850 &, 000 & Diterima \\
\hline H3 & Nostalgia $\rightarrow$ Kepercayaan & 29,996 &, 000 & Diterima \\
\hline H4 & Kepercayaan $\longrightarrow$ Sikap terhadap merek & 18,362 &, 000 & Diterima \\
\hline
\end{tabular}

(Sumber: Data diolah)

Interpretasi:

1. Nilai koefisien jalur 0,265 mengindikasikan, ketika Fitur Keahlian Karakter dianggap semakin Ahli maka akan menjadikan Kepercayaan Pelanggan semakin meningkat.

2. Nilai koefisien jalur 0,555 mengindikasikan, ketika Fitur Nostalgia Karakter dianggap semakin Nostalgi maka akan menjadikan Kepercayaan Pelanggan semakin meningkat.

3. Nilai koefisien jalur 0,034 mengindikasikan, ketika Kepercayaan Konsumen dianggap semakin tinggi maka akan menjadikan Sikap Konsumen tersebut semakin Percaya terhadap suatu Merek.

4. Nilai koefisien jalur 0,638 mengindikasikan, ketika Fitur Relevansi Karakter dianggap semakin Relevan maka akan menjadikan Kepercayaan Pelanggan semakin meningkat.

\section{PEMBAHASAN}

$\mathrm{H}_{1}$ penelitian, menjelaskan bahwa Fitur Keahlian Karakter berpengaruh signifikan terhadap kepercayaan konsumen atas spokes character. Hal tersebut sesuai dengan hasil penelitian Garretson dan Niedrich, (2004) yang menemukan bahwa karakter keahlian dapat menimbulkan kepercayaan konsumen atas spokes character. Silvera dan Austad, (2004) juga berpendapat bahwa keahlian dipercaya sebagai salah satu faktor yang dapat meningkatkan efek persuasif serta mempengaruhi kepercayaan konsumen. Spokes Character dengan tingkat keahlian yang rendah (Clow dan Bacck, 2004:24). Hal ini dikuatkan dengan hasil penelitian Doney dan Cannon, (1997) yang mengindikasikan persepsi dari keahlian penting dalam pembentukan kepercayaan dalam suatu hubungan yang ada.

$\mathrm{H}_{2}$ penelitian, menjelaskan bahwa Fitur Relevansi Karakter berpengaruh signifikan terhadap Kepercayaan Konsumen atas Spokes
Character. Hal tersebut sesuai dengan yang dikemukakan oleh Callcot dan Philips dalam Garretson dan Niedrich, (2004) bahwa konsumen benar-benar mempertimbangkan pentingnya kecocokan atau kesesuaian antara karakter dengan produk. Ide mengenai kecocokan endorser dan produk tersebut dinamakan "match up hypothesis." Kamins, (1990) berpendapat bahwa endorser akan menjadi lebih efektif apabila terdapat kecocokan antara endorser dan produk.

$\mathrm{H}_{3}$ penelitian, menjelaskan bahwa Fitur Relevansi Karakter berpengaruh signifikan terhadap Kepercayaan Konsumen atas Spokes Character. Hal ini sesuai dengan hasil penelitian Garretson dan Niedrich, (2004) yang menemukan bahwa Nostalgia dapat menimbulkan Kepercayaan Konsumen atas Spokes Character. Setiap konsumen memiliki perbedaan dalam merespon suatu stimuli nostalgia, hal ini tergantung memori yang dimiliki. Dalam pembentukan suatu memori terdapat beragam faktor internal dan eksternal yang mempengaruhi, diantaranya: (1) faktor iklan sebagai sebuah pengaruh lingkungan yang dapat mempengaruhi proses psikologi konsumen. Selain itu juga terdapat faktor eksternal lain seperti saran serta pengulangan yang dapat memiliki pengaruh yang amat besar pada proses informasi internal (termasuk memori), (2) Apapun definisi yang digunakan, nostalgia selalu berkonotasi dengan perasaan dan subyektifitas yang berkenaan dengan masa lalu. Emosi secara internal dipindahkan ke dalam suatu obyek mati, suara, atau rasa yang dialami. Komponen emosional tersebut mengarahkan pada penciptaan ilusi memori dengan membantu dalam pembentukan subyektif dari memori. Terlebih lagi, proses pembentukan internal itu sendiri difasilitasi oleh skema pengetahuan, efek imajinasi, dan pengaruh umum lainnya dalam memproses (Aiken, 1999). 
Holbrook dan Schindler dalam Stern, (1992) menyatakan bahwa setiap gender (pria atau wanita) kemungkinan memiliki pengalaman serta cara mengekspresikan nostalgia yang berbeda. Hal ini terkait dengan sifat dasar dari gender, dimana setiap gender yang merasakan nostalgia, mengevaluasi stimuli yang berbeda sebagai nostalgia dan mengartikulasikan respon nostalgia dengan intensitas yang berbeda.

$\mathrm{H}_{4}$ penelitian, menjelaskan bahwa peningkatan Kepercayaan Konsumen akan berimplikasi positif terhadap Sikap Konsumen itu sendiri atas suatu Merek. Hal ini memiliki relevansi faktual atas pembuktian empiris yang telah dilakukan oleh Garretson dan Niedrich (2004) bahwa karakter dapat menciptakan persepsi akan kepercayaan, yang muncul untuk mempengaruhi sikap serta perilaku konsumen. Selain itu, hasil penelitian Garretson dan Niedrich, (2004) juga mengindikasikan bahwa kepercayaan konsumen atas spokes character berpengaruh signifikan terhadap sikap terhadap merek. Hal ini diperkuat dengan pernyataan Goldsmith, Lafferty, dan Newell, (2000) bahwa kepercayaan merupakan elemen dari endorser yang kredibel, dan endorser yang kredibel menunjukkan pengaruh yang positif terhadap sikap terhadap merek maupun sikap terhadap iklan.

\section{PENUTUP \\ Simpulan}

Disimpulkan bahwa $\mathrm{H}_{1}, \quad \mathrm{H}_{2}, \quad \mathrm{H}_{3}, \quad \mathrm{H}_{4}$ penelitian dapat didukung kebenarannya secara empiris, dengan bukti bahwa p-value hasil uji hipotesis penelitian berada di bawah alpha sebesar $5 \%$ dan critical ratio value-nya (CR) berada di atas 2. Dimana fit-test Structure Equation Model (SEM) memiliki kelayakan model analisis yang cukup baik, dengan proporsionalitas closed fit model: Chi-Square $=$ 42,098; Probability = 0,000; CMIN/DF $=14,033$; $\mathrm{GFI}=0,950$; $\mathrm{TLI}=0,988 ; \mathrm{CFI}=0,956$; $\mathrm{RMSEA}$ $=0,978$.

\section{Saran}

Sebagai implikasi akhir hasil penelitian, dapat dikemukakan saran positif bagi Unilever, TBK selaku produsen produk ice cream Paddlepop antara lain; manajemen Unilever dapat meningkatkan karakter relevansi yang dimiliki Lion. Hal ini dapat dilakukan dengan mempertahankan konsistensi penggunaan tema "Petualangan Paddlepop" yang selama ini diaplikasikan dalam promosi paddlepop terutama pada jingle iklan di televisi. Dengan menjaga relevansi antara Lion dan produk paddlepop, maka kepercayaan konsumen atas spokes character juga dapat dipertahankan. Manajemen Unilever dapat mempertahankan bahkan meningkatkan kemampuan karakter Lion dalam menjelaskan produk paddlepop dalam iklan. Manajemen Unilever dapat mempertahankan bahkan meningkatkan kemampuan karakter Lion dalam memberikan memori/kenangan masa lalu yang positif. Hal ini dapat dilakukan dengan menampilkan iklan produk paddlepop dan membuatnya dekat dibenak konsumen. Seyogyanya manajemen Unilever dapat mempertahankan bahkan meningkatkan kepercayaan konsumen atas spokes character Lion. Hal ini dapat dilakukan dengan menjaga kebenaran informasi yang disampaikan Lion agar konsumen tetap memiliki kepercayaan atas spokes character dan nantinya dapat membentuk suatu sikap terhadap merek yang positif.

\section{DAFTAR PUSTAKA}

Aiken, K. Damon. 1999. Manufactured Memories and Nostalgia Advertising. American Marketing Association Conference Proceedings. Vol.10 pg. 44.

Assael, Henry. 1998. Consumer Behavior and Marketing Ations. Sixth Edition. Ohio: South Western College Publishing.

Belch, George E. dan Michael E. Belch. 2004. Marketing and Promotion. Sixth Edition. New York: McGraw Hill Companies,Inc. Callcott, Margaret F. dan Wei-Na Lee. 1994. A Content Analysis of Animation and Animated Spokes-Characters in Television Commercials. Journal of Advertising. Vol. 23 (4) pg. 1.

Clow, Kenneth E. dan Donald Baack. 2004. Integrated Advertising, Promotion, and Marketing. Second Edition. New Jersey: Pearson Education, Inc.

Doney, Patricia M. dan Joseph p. Cannon. 1997. An Examination of the Nature of Trust in Buyer-Seller Relationships. Journal of Marketing. Vol. 61 (2) pg. 35.

Ferdinand, Augusty. 2005. Structural Equation Modelling dalam Penelitian Manajemen. Semarang: Badan Penerbit Universitas Diponegoro.

Ferdinandus, Agustinus. 2016. Tutorial Aplikatif Pengoperasionalan Analisis Konseptual 
Structural Equation Modeling Beserta Implikasinya Dalam Riset Terapan. Prenada Kencana. Jakarta Edisi Revisi.

Garretson, Judith A. dan Ronald W. Niedrich. 2004. Creating Character Trust and Positive Brand Attitudes. Journal of Advertising. Vol. 33 (2) pg. 25.

Ghozali, Imam. 2005. Structural Equation Modelling. Semarang: Badan Penerbit Universitas Diponegoro.

Goldsmith, Ronald E., Barbara A. Lafferty dan Stephen J. Newell. 2000. The Impact of Corporate Credibility and Celebrity Credibility on Consumer Reaction to Advertisements and Brands. Journal of Advertising. Vol. 29 (3) pg. 43.

Hair, Joseph F., Ralph E. Anderson, Ronald L. Tatham dan William C. Black. 1998. Multivariate Data Analysis. Fifth Edition. New Jersey: Prentice Hall.

Kamins, M.A. 1990. An Investigation into the 'Match-up' Hypothesis in Celebrity Advertising: When Beauty may be only Skin Deep. Journal of Advertising. Vol. 19 (1) pp. 4-13.

Kotler, Philip dan Gary Amstrong. 2001. Prinsipprinsip Pemasaran. Edisi Kedelapan. Terjemahan. Jakarta: Penerbit Erlangga.

Lamb, Charles W., Joseph F. Hair, Jr. dan Carl McDaniel. 2001. Pemasaran. Terjemahan. Jakarta: Penerbit Salemba Empat.

Luo., J.T., Peter McGoldrick, Susan Beatty dan Kathleen A. Keeling. 2006. On Screen characters: Their Design and Influence on Consumer Trust. Journal of Service Marketing.

Muehling, Darrel D. dan David E. Sprott. 2004. The Power of Reflection: An Empirical Examination of Nostalgia Advertising Effects. Journal of Advertising. Vol. 33 (3) pg. 25.

Ohanian, Roobina. 1990. Construction and Validation of a Scale to Measure Celebrity. Journal of Advertising. Vol. 19 (3) pg. 39.

Philips, Barbara J. dan Barbara Gyoerick. 1999. The Cow, The Cook, and The Quaker: Fifty Years of Spokes-character Advertising. Journalism and Mass Communication Quarterly. Vol. 76 (4) pg. 713.

Santoso. S. 2002, Tutorial Pengolahan Data SPSS Release 11. Intermedia. Bandung. Edisi Khusus.

Sciffman, Leon G. dan Leslie Lazar Kanuk. 2004. Consumer Behavior. Eight Edition. New Jersey: Pearson Education,Inc.

Silvera, David H. dan Benedikte Austad. 2004. Factors Predicting the Effectiveness of Celebrity Endorsement Advertisements. European Journal of Marketing. Vol. 38 (11/12) pg. 1509.

Stern, Barbara B. 1992. Historical and Personal Nostalgia in advertising Text: The Fin de siècle Effect. Journal of Advertising. Vol. 21 (4) pg. 11.

Tellis, Gerard J. 2004. Effective Advertising. California: Sage Publications, Inc. www.unilever.com 